\title{
Metastasis Breast Cancer
}

\author{
Andrew Hague* \\ Professor of Advanced Medicine, UK
}

*Corresponding author: Andrew Hague, Professor of Advanced Medicine, President of Cell Sonic Limited, UK.

To Cite This Article: Andrew Hague. Metastasis Breast Cancer. Am J Biomed Sci \& Res. 2019 - 1(6). AJBSR.MS.ID.000559. DOI: 10.34297/AJBSR.2019.01.000559

Received: February 15, 2019 | Published: March 21, 2019

\section{Opinion}

When I received the report from the doctor with this photo, I was shocked. We seldom see cancer. It is inside. Here a breast tumour has spread to the skin. This is stage 4 cancer, the stage at which most oncologists have ceased trying to stop the cancer. The lady had lost faith in the usual chemo-radiation methods. They didn't work and had cost her a fortune. Word of mouth led her to a Cell Sonic specialist who was not advertising that Cell Sonic can treat cancer, but the specialist had previous experience and knew that only Cell Sonic could help (Figure 1).

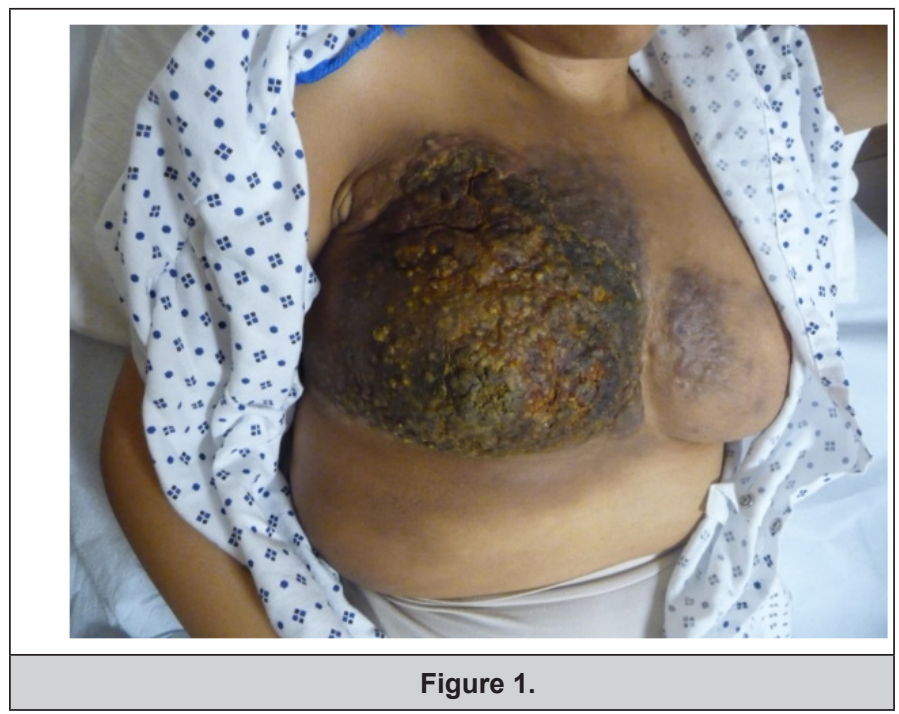

The doctor asked the lady about the pain on a scale of 1 to 10 . She replied 14. It was agony. He gave her one treatment and the pain went away. It is not clear how quickly the pain was quashed, whether it was immediate or within hours. It was also reported that the scales of scabs started to dry out. The doctor was both pleased and perplexed. The result was better than he expected, and he asked for my opinion. I told him that the result was predictable as we know from cancer cases going back almost three years. There are no side effects. On the third day, the patient feels different. The load on their immune system is greatly reduced and this translates to feeling better.

I said to the doctor that he had shifted from cancer to plastic surgery but to not rush into anything. See if the scabs fall off. Will the tumour, causing the swelling, dissipate or need removing surgically? Now benign, there is every chance that the tumour will be removed by the immune system. He should also be aware that with the pain gone from the breasts, she may become aware of other pains hidden by the predominance of the breast pain. In other words, could the cancer have spread to other organs which have not yet been treated? With such visually obvious damage, there had been no scans. Thus far, there are no further reports of cancer elsewhere. 